\title{
KOMPETENCJE ORZECZNICZE SĄDÓW ADMINISTRACYJNYCH A REALIZACJA FUNKCJI OCHRONNEJ PRAW JEDNOSTKI W POSTĘPOWANIU
}

W europejskich systemach prawnych dominujacym modelem sprawowania kontroli działalności administracji publicznej jest powierzenie jej wykonywania kompetencji odrębnego i wyspecjalizowanego sądownictwa administracyjnego. Co do zasady kontrola realizowana jest w trybie weryfikacyjnym (kasacyjnym) bądź w trybie pełnego orzekania ${ }^{1}$. W ramach pierwszego $\mathrm{z}$ wymienionych sądy administracyjne są uprawnione wyłącznie do oceny legalności zaskarżonego aktu organu administracji. W przypadku uwzględnienia skargi dochodzi do jego uchylenia oraz przekazania sprawy do ponownego rozpoznania właściwemu organowi. Sąd jest uprawniony do badania ustaleń co do prawa, co jednak nie wyłącza możliwości oceny prawidłowości dokonanych przez organ ustaleń faktycznych. W trybie pełnego orzekania wyrok sądu rozstrzyga sprawę, tym samym zastępuje zaskarżony akt organu administracji. Sąd jest władny moca decyzji orzeczniczej wzruszyć akt, może on zobowiązać organ do wydania aktu określonej treści, może sformułować zakaz określonego działania bądź nakaz zaprzestania danej czynności. Jest sądem faktu i prawa, ma więc uprawnienie do przeprowadzenia pełnego postępowania wyjaśniającego.

Mając na względzie powyższy podział, przyjrzyjmy się rozwiązaniom prawnym przyjętym w trzech systemach europejskich, w których doszło do modyfikacji modelu kasacyjnego, co w konsekwencji wzmocniło sądy administracyjne $\mathrm{w}$ realizowanej przez nie funkcji ochrony praw jednostki w jej stosunkach $\mathrm{z}$ administracja.

Niemieckie rozwiązania prawne powierzają kontrolę działalności administracji publicznej niezależnym i odrębnym sądom administracyjnym działającym w systemie trójinstancyjnym. Sądy są uprawnione do kontroli legalności aktów lub czynności administracji publicznej, które podlegają uchyleniu w zakresie, w jakim naruszaja prawo, a w konsekwencji łamia prawa podmiotu skarżącego. Warto podkreślić, że regulacja niemieckiej ustawy ${ }^{2}$ stanowi konkretyzację art. 19 ust. 4 Ustawy zasadniczej³ , zgodnie z którym każdy, czyje

${ }^{1}$ Por.: Z. Kmieciak, Wykonanie wyroku sqdu administracyjnego, w: R. Hauser, Z. Niewiadomski, Z. Wróbel (red.), Sqdowa kontrola administracji publicznej, Warszawa 2014, s. 641-643; Z. Kmieciak, Postepowanie administracyjne i sqdowoadministracyjne a prawo europejskie, Warszawa 2010, s. 103.

${ }^{2}$ Verwaltungsgerichtsordnung, BGBl.I S.2940 (dalej jako: VwGO).

${ }^{3}$ Grundgesetz, BGBl.I S.2438. 
prawa zostały naruszone przez władzę publiczna, ma prawo ich dochodzenia na drodze sądowej. Unormowanie rangi konstytucyjnej tworzy podstawy indywidualnej ochrony jednostki przed bezprawnymi działaniami organów administracji publicznej. Jest ono traktowane jako norma centralna, która odwołujac się wprost do praw podstawowych, ogranicza działania administracji w sferze praw podstawowych, poddając ją ochronie sądowej. W orzecznictwie BVfG obowiązuje pogląd, że gwarantuje ono obywatelom prawo dostępu do sądu, prawo do efektywnej ochrony sądowej oraz realizację wciąż kształtującej się zasady rzeczywistej ochrony sądowej. Przyjmuje się, że do uruchomienia drogi sądowej wystarczajace jest samo prawdopodobieństwo naruszenia prawa, co oznacza, iż mamy do czynienia z takim mechanizmem ochrony, który skutecznie ma niwelować ograniczenia dostępu do poszczególnych instancji sądowych oraz ma realizować zasadę rzetelnej procedury sądowej ${ }^{4}$.

Niemiecki system prawny wprowadza kasacyjny model orzekania, który wzbogacony jest o kompetencję do merytorycznego rozstrzygnięcia sprawy. Sąd administracyjny może wydać tzw. bezpośrednie orzeczenie merytoryczne ${ }^{5}$, czyli jest upoważniony do sformułowania wiążącego organy administracji nakazu wydania decyzji wraz z wytycznymi co do jej treści. Rozwiąanie takie uzasadniane szybkością i efektywnością procesową dotyczy określonych kategorii spraw i jest dopuszczalne po spełnieniu określonych warunków. Ustawa przewiduje, że wyrok rozstrzygający sprawę co do istoty może zapaść, jeżeli stan faktyczny został ustalony w sposób pełny i prawidłowy, a sprawa jest dojrzała do rozstrzygnięcia. Orzeczenie merytoryczne nie może zapaść, jeżeli organ korzystał z przysługującego mu uznania administracyjnego (§113 VwGO).

$\mathrm{Na}$ szczególną uwagę zasługuje niemiecka regulacja skarg do sądu administracyjnego. W ustawie zrezygnowano z zasady enumeracji i wprowadzono zapis stanowiący, iż ochrona prawna przed władczym działaniem lub zaniechaniem administracji przysługuje niezależnie od ich formy prawnej. Każde więc nieuprawnione zachowanie organu może znaleźć swój odpowiednik w rodzaju skargi. Taki otwarty system daje ustawodawcy, ale również orzecznictwu, możliwość wprowadzania kolejnych ich typów dla określonych sytuacji prawnych. Zróżnicowany charakter skarg zależy od rodzaju zaskarżanej czynności oraz skutku, jaki zamierza osiagnać legitymowany podmiot. Uprawniony może wystapić ze skargą o uchylenie aktu administracyjnego, o spełnienie świadczenia, o ustalenie istnienia stosunku prawnego oraz ze skargą o kontrolę normy wydanej przez administrację ${ }^{6}$.

${ }^{4}$ M. Kunnecke, Tradition and Change in Administrative Law: An Anglo-German Comparison, Berlin-Heidelberg 2007, s. 28-30.

${ }^{5}$ M. Kamiński, Orzekanie sqdów administracyjnych. Uwagi na tle szwajcarskiego, austriackiego i niemieckiego systemu prawnego, w: I. Lipowicz, Z. Kmieciak (red.), Przyszłość sadownictwa administracyjnego w Polsce z uwzględnieniem tendencji europejskich, Warszawa 2012, s. 132.

${ }^{6}$ Por. A. J. Bok, Judicial review of administrative decision: recours objectif or recours subjectif?, w: F. Stroink, E. van der Linden, Judicial Lawmaking and Administrative Law, Antwerpen-Oxford 2005, s. 162-168; W. Piątek, Podstawy skargi kasacyjnej w postepowaniu sqdowoadministracyjnym, Warszawa 2011, s. 77; Ł. Baczyński, R. Hauser, Niemieckie ogólne sqdownictwo administracyjne, „Zeszyty Naukowe Sądownictwa Administracyjnego” 4-5, 2006, s. 207. 
W Austrii system sądownictwa administracyjnego uzyskał zupełnie nowy kształt na mocy noweli konstytucyjnej ${ }^{7}$, która wprowadziła organizację dwuinstancyjną oraz zmodyfikowała model uprawnień orzeczniczych. Zakresem właściwości objęto sprawy ze skarg na akty lub czynności administracji z powodu ich sprzeczności z prawem, wymienione w regulacji m.in. na decyzje, środki władcze w postaci nakazu i przymusu, brak wydania decyzji oraz na tzw. nietypowe czynności administracji na mocy ustawy federalnej bądź krajowej (art. 130).

Skargę może wnieść każdy, kto twierdzi, że przez wydanie decyzji naruszono jego prawa, a w braku realizacji obowiązku wydania rozstrzygnięcia przez organ - każdy, kto uważa się za uprawnionego do dochodzenia jego wypełnienia (art. 130 ust. 2 i 3 ).

Model uprawnień orzeczniczych oparty na zasadzie kompetencji kasacyjnej, podobnie jak w Niemczech, wzbogacony został o uprawnienie sądów do wydawania rozstrzygnięć merytorycznych - obligatoryjnie w sprawach karno-administracyjnych, w sprawach pozostałych, jeżeli stan faktyczny nie budzi wątpliwości bądź samodzielne jego ustalenie jest uzasadnione względami szybkości lub kosztami postępowania (art. 130 ust. 4). Federalny Trybunał Administracyjny, jako sąd rewizyjny, ma prawo do orzekania reformatoryjnego, o ile sprawa dojrzała do rozstrzygnięcia i jest to uzasadnione względami prostoty, celowości postępowania oraz oszczędnością kosztów. Warto podkreślić, że austriackie sądownictwo administracyjne od początku swego istnienia wyposażone było wyłącznie w kompetencje kasacyjne i przez tak długi okres nie mogło zmieniać ani kształtować treści aktów organów administracji publicznej. Za wyjątek uznawano możliwość wydania orzeczenia merytorycznego w przypadku uwzględnienia skargi na bezczynność administracji, a jako element orzeczenia quasi-reformatoryjnego traktowano związanie organu ocena prawną wyrażoną w wyroku. Regulacje te spotykały się z zarzutami niezgodności z postanowieniami europejskiej Konwencji o ochronie praw człowieka i podstawowych wolności, co przyczyniło się do szerokich zmian przyjętych w ostatnich latach w ustawodawstwie ${ }^{8}$.

W Polsce sądownictwo administracyjne działa jako odrębny pion władzy sądowniczej. Tworzy system dwuinstancyjny z wojewódzkimi sądami administracyjnymi oraz Naczelnym Sądem Administracyjnym.

Stosownie do regulacji zamieszczonej w Konstytucji sądy sprawują kontrolę działalności administracji publicznej, dokonując oceny, czy załatwienie sprawy $\mathrm{w}$ administracyjnym toku instancji przebiegało zgodnie z prawem. Przyjęta reguła kompetencji kasacyjnej prowadzi do zniesienia nielegalnego działania organu administracji publicznej przez zastosowanie określonej sankcji. W przypadku uwzględnienia skargi na działanie, bezczynność lub przewlekłe prowadzenie postępowania sąd może zastosować sankcje nieważ-

\footnotetext{
7 Verwaltungsgerichtsbarkeits - Nowelle2012, BGBl. 51/2012.

8 Szerzej: Z. Kmieciak, P. Florianowicz-Błachut, Austria-reforma sqdownictwa administracyjnego. Wybór przepisów znowelizowanych 51. Ustawa federalna Verwaltungsgerichtsbarkeits-Novelle 2012, „Zeszyty Naukowe Sądownictwa Administracyjnego” 4, 2013, s. 187-189; A. Krawczyk, Reforma sadownictwa administracyjnego w Austrii, „Państwo i Prawo” 2013, z. 4.
} 
ności, wzruszalności, bezskuteczności czynności bądź określić wprost obowiązek podjęcia określonego działania ${ }^{9}$. Co do zasady, sąd przekazuje sprawę właściwemu organowi celem jej ponownego rozpatrzenia przy uwzględnieniu wiążącej oceny prawnej oraz wskazań co do dalszego postępowania. Dodatkowo sąd jest wyposażony w kompetencję orzekania merytorycznego na warunkach przewidzianych $\mathrm{w}$ ustawie, o czym będzie mowa $\mathrm{w}$ dalszej części rozważań ${ }^{10}$.

Reguła kompetencji kasacyjnej dotyczy również orzecznictwa NSA, który sprawuje nadzór judykacyjny nad kontrolą realizowaną przez WSA. Także i w tym przypadku doznaje ona wzbogacenia przez wprowadzenie trybu reformatoryjnego w procesie orzekania (art. 188 p.p.s.a.). Sąd może bowiem samodzielnie rozpoznać skargę, o ile uzna, że istota sprawy została dostatecznie wyjaśniona.

Z przeprowadzonych porównań wynika, że model kasacyjny właściwy dla przedstawionych systemów prawnych doznaje modyfikacji przez włączanie w jego ramy dodatkowych środków ochrony charakterystycznych dla modelu pełnej jurysdykcji, głównie w postaci orzeczeń merytorycznych.

Wśród przyczyn takiego stanu rzeczy najczęściej podnosi się niski poziom efektywności ochrony realizowanej przez sąd, szczególnie dotkliwy na etapie wykonania wyroku kasacyjnego. Zwraca się uwagę na odnotowane przypadki niewykonania orzeczenia sądu przez organ administracyjny w całości lub w części, ignorowanie oceny prawnej, niezastosowanie się do wskazań co do dalszego postępowania, a nawet polemizowanie z niektórymi argumentami przedstawionymi przez są ${ }^{11}$. Jednak kwestią o podstawowym znaczeniu staje się naturalne ograniczenie efektywności jurysdykcji typu kasatoryjnego związane $\mathrm{z}$ tym, że wyrok wraz $\mathrm{z}$ prawidłowo skonstruowanym uzasadnieniem kreuje pewna swobodę $\mathrm{w}$ wyborze opcji ponownego rozstrzygnięcia sprawy przez organ. Ten swoisty luz decyzyjny w praktyce administracyjnej może być nadużywany, co w konsekwencji prowadzi do ponownego zaskarżenia aktu. W rezultacie sprawa może dwu- lub trzykrotnie powracać do sądu w wyniku jej zaskarżenia, co rodzi tzw. efekt jo-jo rozumiany jako rozpatrywanie jej na przemian przez organy administracji i sądy administracyjne ${ }^{12}$.

Zabieg wzbogacania kasacyjnych kompetencji orzeczniczych o uprawnienie sądu do samodzielnego rozstrzygania sprawy niewątpliwie przyczynia się do realizacji postulatu szybkości i efektywności w postępowaniu sądowoadministracyjnym. Należy wszakże tę zmianę modelu uprawnień sądów administracyjnych widzieć w szerszej perspektywie, w kontekście przeobrażeń, jakim podlega przestrzeń prawa, oraz nowej roli sądu administracyjnego - gwaranta ochrony praw jednostki.

${ }^{9}$ B. Adamiak, J. Borkowski, Metodyka pracy sędziego w sprawach administracyjnych, Warszawa 2015 , s. 241.

${ }^{10}$ Ustawa z 30 sierpnia 2002 r. - Prawo o postępowaniu przed sądami administracyjnymi, Dz. U. 2002, Nr 153, poz. 1270 (dalej jako: p.p.s.a.).

${ }^{11}$ R. Hauser, Wstępne zatożenia nowelizacji ustawy - Prawo o postępowaniu przed sqdami administracyjnymi, „Państwo i Prawo” 2013, z. 2, s. 22.

${ }^{12}$ Z. Kmieciak, op. cit., s. 643. 
Wzmocnienie funkcji ochronnej jednostki w jej stosunkach z administracja w postępowaniu sądowoadministracyjnym stanowi realizację koncepcji efektywnej ochrony sądowej rozwijanej w europejskim case law i soft law.

W orzecznictwie ETPC efektywna ochrona sądowa stanowi jeden ze składników prawa do sądu. Uznaje się ją za wartość proceduralną i wymienia obok niezawisłości sądu, rzetelności i rozsądnego czasu postępowania, uczciwości i publicznego charakteru rozprawy. Podkreśla się, że wszystkie wymienione powinny zostać spełnione dla właściwej realizacji prawa do sądu w sferze kontroli administracji prowadzonej co najmniej z punktu widzenia legalności ${ }^{13}$.

Warto zauważyć, że jeszcze w latach dziewięćdziesiątych Trybunał wiązał ją wprost z wykonalnością orzeczeń sądowych. W swoich wyrokach kładł nacisk na realizację prawomocnego orzeczenia sądowego w rozsąnnym terminie, uznając, że jest to integralna część procesu ${ }^{14}$ oraz że organy administracji mają obowiązek podporządkować się wyrokowi sądu i wydać decyzję zgodną z jego treścią. Przestrzegał, że niewykonanie traktowane może być jako bezczynność organu i może prowadzić do naruszenia regulacji konwencyjnej ${ }^{15}$.

Szersze rozumienie efektywności ochrony sądowej przyjęte zostało w Rekomendacji w sprawie egzekucji decyzji administracyjnych i orzeczeń sądowych $\mathrm{w}$ prawie administracyjnym ${ }^{16}$. Wskazano tu bowiem na dwa jej dwa aspekty: osiagnięcie rezultatu prawidłowego co do oceny prawnej działań administracji oraz doprowadzenie do stanu rzeczy zgodnego z prawem w następstwie wyroku sądu. Postępowanie będzie efektywne, jeżeli sąd w razie uwzględnienia skargi, stosownie do wymagań określonej procedury, zastosuje adekwatny środek prawny. Rozstrzygnięcie w sprawie powinno doprowadzić do usunięcia naruszającego prawo działania organu, i to zarówno w jurysdykcji typu kasatoryjnego, jak i jurysdykcji pełnego orzekania.

Rekomendacja w sprawie sądowej kontroli aktów administracyjnych ${ }^{17}$ jeszcze mocniej powiązała skuteczną kontrolę z pozycją jednostki w procesie. Uznała ją bowiem za istotny element systemu ochrony praw człowieka. Określiła minimalne standardy ochrony jednostki w jej stosunkach $\mathrm{z}$ administracja, przyjmując, że w przypadku stwierdzenia naruszenia prawa sąd powinien być uprawniony przynajmniej do pozbawienia decyzji mocy wiążącej, a w razie konieczności także do ponownego przekazania sprawy organowi. Wskazała na obowiązek wprowadzenia instrumentów prawnych, które doprowadzą do rezultatu zamierzonego przez sąd. Położyła mocny akcent na możliwość wydania orzeczenia merytorycznego w sprawie - orzeczenia zastępującego akt administracyjny, które skutecznie rozstrzyga spór o uprawnienie jednostki.

${ }^{13}$ Z. Kmieciak, Europejskie standardy prawa do sqdu w sprawach z dziedziny administracji publicznej, w: R. Hauser, Z. Niewiadomski, A. Wróbel (red.), Europeizacja prawa administracyjnego, Warszawa 2014, s. 401.

${ }_{14}$ Wyrok ETPC z 23 marca 1994 r. w sprawie 15797/89 Di Pede v. Włochy, Lex, nr 80163.

15 Wyrok ETPC z 19 marca 1997 r. w sprawie 18357/91 Hornsby v. Grecja, Lex, nr 79713.

${ }^{16}$ Recommendation Rec (2003)16 of the Committee of Ministers to member states on the execution of administrative and judicial decisions in the field of administrative law, www.coe.int/Doc.

${ }^{17}$ Recommedation Rec (2004)20E of Committee of Ministers to member states on judicial review of administrative acts, www.coe.int/Doc. 
Efektywna ochrona sądowa gwarantowana jest również regulacjami prawa Unii Europejskiej. Jeszcze przed wejściem w życie Traktatu z Lizbony obecna była w orzecznictwie TSUE, które uznawało ja za zasadę ogólną prawa wspólnotowego, wywodząca się ze wspólnych tradycji konstytucyjnych państw członkowskich i chroniona z mocy art. 6 oraz art. 13 EKPC. Obecnie prawo do skutecznego środka ochrony prawnej lub ochrony sądowej statuuje art. 47 Karty praw podstawowych. Stosownie do regulacji przysługuje ono każdemu, czyje prawa i wolności gwarantowane prawem Unii zostały naruszone. Ma charakter instrumentalny wobec praw podmiotowych, ma zapobiegać bowiem ewentualnym ich naruszeniom, a w sytuacji stwierdzenia naruszenia ma służyć kompensacji doznanej szkody albo umożliwiać zastosowanie środka o charakterze represyjnym. Szeroko ujęta funkcja ochronna powinna być realizowana zarówno w ramach środków prawnych o charakterze proceduralnym oraz tych opartych na prawie materialnym, które służą wykonaniu praw UE ${ }^{18}$.

Prawo do efektywnej ochrony sądowej ma chronić prawa i wolności szeroko pojęte: te gwarantowane w Karcie, prawa podstawowe uznane na mocy norm prawa pierwotnego i pochodnego, norm prawa międzynarodowego oraz prawa i wolności uznane w państwach członkowskich ${ }^{19}$. Ochrona powinna być realizowana $\mathrm{w}$ razie ich naruszenia przez bezprawne działanie badź zaniechanie organu władzy publicznej, w tym organów administracji publicznej w zakresie, w jakim stosują one prawo UE. Zadaniem państwa jest, najogólniej rzecz ujmując, wyznaczenie sądów właściwych dla rozpatrzenia sprawy i ustanowienie odpowiednich procedur, przy czym stosowany środek ochrony winien być skuteczny w sensie faktycznym oraz prawnym ${ }^{20}$.

Z powyższych rozważań wynika, że koncepcja efektywnej ochrony sądowej rozwijana w porządku konwencyjnym i w prawie UE powiązana jest ściśle z publicznymi prawami podmiotowymi i ma znaczenie podstawowe dla ich ochrony. Prawa te bowiem kształtują sytuację podmiotowa jednostki wobec państwa. Ze względu na posiadaną strukturę prawa do czegoś, wolności lub kompetencji, stawiaja jednostkę w pozycji uprawnionego do wymagania określonego zachowania od organów władzy publicznej. I co istotne, pozostaja w określonej relacji względem obiektywnego porządku prawnego, takiej, że wyznaczają jego granice formalne i treściowe ${ }^{21}$. „Normy obiektywnego porządku prawnego muszą co najmniej nie przekraczać granic wyznaczonych normami gwarantującymi prawa podstawowe albo być z nimi zgodne, ewentualnie spójne lub zapewniać ich skuteczną realizację"22. Prawa podmiotowe wzmacniają zatem pozycję jednostki w stosunkach $\mathrm{z}$ organami administracji, wzmacniają też rolę sądu administracyjnego w realizacji funkcji ochronnej. Nie ulega wątpliwości, że sąd administracyjny powołany został, by chronić prawa i wol-

\footnotetext{
18 A. Wróbel (red.), Karta Praw Podstawowych Unii Europejskiej. Komentarz, Warszawa 2013, s. 1202-1203.

19 Ibidem, s. 1205.

${ }^{20}$ Idem, s. 1177.

21 A. Wróbel, Prawo podmiotowe publiczne, w: R. Hauser, Z. Niewiadomski, A. Wróbel (red.), Instytucje prawa administracyjnego, Warszawa 2015, s. 330.

22 Ibidem, s. 353.
} 
ności jednostki. Jest to jego funkcja podstawowa ${ }^{23}$. Uznanie jej prymatu ma duże znaczenie dla uzasadnienia przeobrażeń, jakie następują w europejskich systemach sądownictwa administracyjnego co do wzbogacania modelu kompetencji kasatoryjnych o środki prawne znane z trybu pełnego orzekania.

Model jurysdykcji kasatoryjnej nakierowany był od początku jego wykonywania na uzyskanie formalnie pojmowanego stanu zgodności z prawem, czyli na ochronę obiektywnego porządku prawnego. Sąd administracyjny, realizując kontrolę aktów administracyjnych, odwoływał się do wzorca legalności w wąskim rozumieniu, czyli normy prawnej zawartej w ustawie. Miało to związek z obowiąująca wizją prawa zamkniętego w tekście prawnym. Koncepcja prawa właściwa dla wczesnego pozytywizmu prawniczego wiązała pojęcie prawa z ogółem aktów normatywnych - tekstów prawnych. Prawo utożsamiane było z szeroko pojętą ustawą podejmowaną przez prawodawcę, a każde rozstrzygnięcie sądu musiało być dedukowalne z treści przepisów. Prawo należało postrzegać jako fakt i akt prawodawczy był tym faktem, który stanowić miał podstawowy punkt odniesienia dla wszelkich analiz prawniczych. Taka koncepcja „wiązała” prawnika z tekstem ustawy i przedstawiała prawo jako gotowy i skończony przedmiot poznania zewnętrzny w stosunku do podmiotu badajacego ${ }^{24}$.

Koncepcja uznająca, że prawo jest obiektem gotowym, więc niewymagajacym opracowania, czyniła z sędziego „usta ustawy”, stawiała go w pozycji tego, kto powinien stać na straży wyrażonej w ustawie woli politycznego suwerena. Innymi słowy, wiązała go z dbałością o zapewnienie właściwej ochrony obiektywnie postrzeganemu porządkowi prawnemu. „Formalnie pojęta idea bezpieczeństwa prawnego była jedyną wartościa, którą system prawny powinien był realizować i która miała pierwszeństwo przed materialnie pojętą idea sprawiedliwości”25.

Nie ulega wątpliwości, że prawo w pierwszej kolejności wysłowione jest w tekście prawnym - tekst będzie więc nadal dla prawnika podstawowym punktem odniesienia. Współcześnie jednak prawo wyrażone w języku nie posiada jednej i niezmiennej treści. Nie można traktować go jako danego przez prawodawcę i gotowego do odczytania oraz zastosowania. Jest tym, co należy zrekonstruować w procesie dochodzenia do właściwego rozstrzygnięcia, w procesie, w którym konieczne jest ważenie zasad prawnych i uwzględnianie różnych argumentów. Tekst prawny opracowany w języku naturalnym i zawierający regulacje generalno-abstrakcyjne nie może zostać bezpośrednio zastosowany do sytuacji indywidualno-konkretnej. Wymaga wykładni dokonywanej przez sąd, która odwołuje się do zasad prawnych stanowiących istotną część systemu prawa i nie może opierać się na wąsko pojętej zasadzie legalności ${ }^{26}$.

${ }^{23}$ Por. W. Sawczyn, Konstytucyjne podstawy sqdownictwa administracyjnego, w: R. Hauser, Z. Niewiadomski, A. Wróbel (red.), Sqdowa kontrola administracji publicznej, Warszawa 2014, s. 83.

${ }^{24}$ Por. M. Zirk-Sadowski, Wprowadzenie do filozofii prawa, Warszawa 2011, s. 145-146.

${ }^{25}$ R. Sarkowicz, J. Stelmach, Teoria prawa, Kraków 1998, s. 180.

${ }^{26}$ Szerzej: M. Zirk-Sadowski, Pojęcie, koncepcje i przebieg wyktadni prawa administracyjnego, w: R. Hauser, Z. Niewiadomski, A. Wróbel (red.), Wykładnia w prawie administracyjnym, Warszawa 2015, s. 142. 
Przyjęcie argumentacyjno-dyskursywnego modelu prawa stawia w nowej roli sędziego. Skoro znaczenie normy prawnej konstytuuje się w podejmowanych zabiegach rekonstrukcyjno-interpretacyjnych, akcent przesunięty zostaje z przedmiotu na podmiot interpretujący. Sędzia dokonuje wielopłaszczyznowej rekonstrukcji normy prawnej i jest tym, kto odnajduje jej znaczenie i właściwe rozstrzygnięcie danego przypadku. Jednocześnie w sposób odpowiedzialny wpływa na rzeczywistość prawną. Bierze udział w dyskursie, który prowadzony jest wielopodmiotowo, opartym na ważeniu różnych, często odmiennych argumentów oraz zasadzie wzajemnej współpracy organów państwa.

Nie ulega wątpliwości, że sądy administracyjne uczestniczą w stale rozwijającym się dyskursie praw i wolności opartym na ważeniu zasad. Można tenże dyskurs określić mianem wspólnotowego, jeżeli brać pod uwagę wpływ orzecznictwa ETPC oraz TSUE, które konstruuje określone standardy stosowane w orzecznictwie sądów krajowych. Można postrzegać go jako dyskurs konstytucyjny, wiążąc wprost z postanowieniami Konstytucji o prawach i wolnościach jednostki, jakie moga mieć bezpośrednie zastosowanie w procesie orzekania przez sądy, bądź z wpływem orzecznictwa trybunałów konstytucyjnych. Trafnie podnosi się, że orzecznictwo sądów konstytucyjnych w Europie chroni spójność hierarchicznego systemu prawa, ale przede wszystkim stoi na straży systemu wartości zawartego w Konstytucji. Konstytucyjny katalog praw $\mathrm{i}$ wolności jest $\mathrm{w}$ tym ujęciu niezwykle istotny. Jest traktowany jako wzorzec kontroli konstytucyjności prawa. A kontrola konstytucyjności traktowana jest jako ważny instrument służący ochronie tych praw ${ }^{27}$. Warto przypomnieć, niejako wyprzedzając dalszy tok rozważań, konstatację Ch. Starcka, że władza sądów, które realizują funkcję ochrony obywatela przed bezprawnymi działaniami administracji publicznej, wyraża się przede wszystkim w regułach kształtujacych orzeczenia ${ }^{28}$.

W polskiej procedurze rozstrzygnięcia sądów administracyjnych mają postać wyroków kasatoryjnych bądź merytorycznych. Przytoczona klasyfikacja oparta na kryterium treści orzeczenia, jakiego może żądać uprawniony ${ }^{29}$, w naszym porządku prawnym ma znaczenie drugorzędne, ze względu na obowiązywanie reguły kompetencji kasacyjnych. Jednak dla celów niniejszych rozważań jest istotna.

Sądy administracyjne dokonują kontroli działalności administracji publicznej. W rezultacie w modelu kasacyjnym „orzekanie [...] oznacza przeobrażenie rezultatów kontroli lub rezultatów rozpoznania w ostateczną formę wypowiedzi zawierająca sformułowanie zwrotu stosunkowego o zgodności (niezgodności) aktu lub czynności organu z prawem, a ściślej z normą dopełnienia"30. O tym, jaką formę przydać należy wyrokowi sądu oraz jaka treść winna zostać w nim zawarta, decyduje przepis ustawy (art. 145-151 p.p.s.a.). Sąd uwzględ-

${ }^{27}$ Por. E. Mak, Judicial Decision-Making in a Globalised World: A Comparative Analysis, Oxford-Portland 2013, s. 69-79.

${ }^{28}$ C. Starck, Kontrola administracji przez ogólne sqdy administracyjne $w$ Niemczech, w: I. Skrzydło-Niżnik (red.), Instytucje współczesnego prawa administracyjnego. Księga pamiatkowa prof. dr. hab. J Filipka, Kraków 2001, s. 663.

${ }^{29}$ M. Romańska, Skuteczność orzeczeń sqdów administracyjnych, Warszawa 2010, s. 158.

${ }^{30}$ Ibidem, s. 50. 
niając skargę, może uchylić akt, stwierdzić nieważność bądź niezgodność z prawem albo bezskuteczność zaskarżonego aktu (czynności). W przypadku bezczynności organu może zobowiązać go do podjęcia określonej aktywności $\mathrm{w}$ odpowiednim terminie. Co do zasady rozstrzygnięcie kasatoryjne eliminuje sprzeczny z prawem akt z obrotu prawnego ze skutkiem ex tunc albo ex nunc. Sprawa wraca do właściwego organu w celu ponownego jej rozstrzygnięcia z uwzględnieniem wiążącego stanowiska sądu wyrażonego w wyroku.

Model kasacyjny wiąże się z ściśle wyznaczonym przez ustawodawcę zakresem uprawnień orzeczniczych sądu administracyjnego oraz z precyzyjnym określeniem rodzaju rozstrzygnięć, jakie zapaść moga w razie stwierdzenia wystapienia wymienionej w ustawie wady kontrolowanego działania organu administracji. Ograniczony przez ustawodawcę katalog wyroków wypowiedzi sądu oraz powiązanie ich ze ściśle wyznaczonymi następstwami stawia na pierwszym miejscu uprawnienia kontrolne, które służą przede wszystkim funkcji ochrony obiektywnego porzadku prawnego, a nie funkcji ochrony praw i wolności jednostki. Oświadczenia sądu zawierają w swej treści jedynie sformułowanie o wyniku przeprowadzonej kontroli, która w całości nastawiona jest na skasowanie działania organu administracji jako nieodpowiadającego wzorcowi, z punktu widzenia którego kontrola była przeprowadzana ${ }^{31}$.

Model kasatoryjny nie daje sądom możliwości efektywnego wypowiedzenia się w danej sprawie. Po pierwsze, sąd administracyjny, wydając wyrok, nie może przeprowadzić egzekucji co do jego treści stanowiącej istotny komunikat o nielegalności działań administracji. Po drugie, sąd nie może wejść w posiadanie wiedzy o zastosowaniu się przez organ do wiążącej części jego wyroku, jaka jest ocena prawna oraz wskazania co do dalszego postępowania. Nie posiada on instrumentów, jakie pozwoliłyby zbadać wykonalność orzeczenia. Dopiero kolejne wniesienie skargi pozwala ocenić przyczyny bezczynności organu bądź rodzaj popełnionych błędów. W praktyce, o czym była już mowa, sprawa może kilkakrotnie powracać do sądu, co określa się jako kaskadę kasacji. Po trzecie, sąd administracyjny, działając jako sąd kasacyjny, występuje z głosem słabszym w dyskursach prawnych ze względu na wykazane słabości. Właściwa realizacja orzeczenia ma być gwarancja przestrzegania podstawowych wartości proceduralnych oraz zasad zapewniajacych jednostce ochronę w dochodzeniu przez nią naruszonych praw i wolności. W tym kontekście mówi się, że opisywany model często pozostaje niezrozumiały dla stron postępowania i nie odpowiada ich poczuciu sprawiedliwości ${ }^{32}$.

Drugim rodzajem wyroków w postępowaniu przed sądami administracyjnymi są orzeczenia merytoryczne. Ich istota polega na tym, że „sąd administracyjny przejmuje do rozstrzygnięcia sprawę z zakresu administracji publicznej, która uprzednio została załatwiona (została pozostawiona bez załatwienia) przez organ administracji publicznej. Sąd administracyjny, orzekając meryto-

31 Ibidem, s. 160 .

32 A. Skoczylas, Stan $i$ obecne problemy sqdownictwa administracyjnego, w: I. Lipowicz, Z. Kmieciak (red.), op. cit., s. 8. 
rycznie i bezpośrednio co do „sprawy administracyjnej”, kształtuje prawa lub obowiązki materialnoprawne (lub procesowe) skarżącego"33.

W polskich regulacjach prawnych orzeczenia merytoryczne traktować należy jako wyjątek od przyjętej reguły kasacyjnej. Rozwiązania obowiązującego modelu, stosownie do postanowień Konstytucji, nie pozwalają na zastępowanie przez sądy organów administracji publicznej w realizacji nałożonych na nie uprawnień i obowiązków ${ }^{34}$.

Regulacja podstawowa, która przyznaje sądom administracyjnym kompetencje do samodzielnego rozstrzygania sprawy, zawarta została w art. 145a p.p.s.a. Wyposaża ona sądy w prawo zobowiązania organu do podjęcia aktu określonej treści (wskazania sposobu załatwienia sprawy lub jej rozstrzygnięcia) w przypadku uchylenia przez sąd decyzji lub postanowienia ze względu na naruszenie przez organ przepisów prawa materialnego, które miało wpływ na wynik postępowania, oraz w razie stwierdzenia nieważności powyższych aktów, gdy zachodzą przyczyny określone w przepisach. Aktualizacja obowiązku sądu wymaga spełnienia przesłanek wymienionych w ustawie oraz faktu, że dane rozstrzygnięcie nie zostało pozostawione uznaniu organu.

Regulacja art. $154 \S 2$ p.p.s.a. przyznaje sądom administracyjnym kompetencje do wydania orzeczenia stwierdzającego istnienie bądź nieistnienie uprawnienia lub obowiązku. Jest to więc orzeczenie zastępujące akt lub czynność organu administracji, do wydania którego konieczne jest łączne spełnienie przesłanek wymienionych w ustawie: sąd wymierzył organowi grzywnę, na wydanie orzeczenia pozwala charakter sprawy, a jej okoliczności faktyczne i prawne nie budzą uzasadnionych wątpliwości.

Kolejne wyjątki od zasady orzekania kasatoryjnego przewidziane są w regulacji art. $146 \S 2$, art. $149 \S 1$ b p.p.s.a. Istotne jest również uprawnienie do orzekania reformatoryjnego unormowane w art. 188 ustawy zastrzeżone dla Naczelnego Sądu Administracyjnego. Stosownie do treści przepisu Sąd, uchylając zaskarżone orzeczenia, rozpoznaje skargę, jeżeli uzna, że istota sprawy została wyjaśniona w sposób dostateczny. Zatem NSA samodzielnie orzeka w przedmiocie zasadności skargi, w tym stosuje także formę orzeczenia merytorycznego ${ }^{35}$.

Doniosłość kompetencji sądu administracyjnego do merytorycznego rozstrzygnięcia sprawy wiąże się tym, że formułuje on własną wypowiedź, która poddawana jest egzekucji co do treści w oznaczonym terminie. W konsekwencji sąd będzie posiadał wiedzę o wykonaniu orzeczenia - zgodnie z regulacja art. $145 \S 2$ i 3 p.p.s.a. organ ma obowiąek powiadomienia o realizacji wyroku, a w jego braku przewiduje się możliwość nałożenia na niego grzywny; ponadto stronie służy prawo do wniesienia odrębnej skargi o stwierdzenie istnienia bądź nieistnienia uprawnienia lub obowiązku.

${ }^{33}$ M. Kamiński, op. cit., s. 121.

${ }^{34}$ R. Hauser et al. (red.), Prawo o postępowaniu przed sqdami administracyjnymi: komentarz, Warszawa 2015, s. 600-603.

${ }^{35}$ Szerzej: B. Adamiak, J. Borkowski, Postepowanie administracyjne i sqdowoadministracyjne, Warszawa 2015, s. 470 i n.; H. Knysiak-Sudyka, M. Romańska, T. Woś, Postępowanie sqdowoadministracyjne, Warszawa 2015, s. 288-305. 
Sąd administracyjny został tym samym wyposażony w określona władzę, która wzmacnia jego głos w dyskursach stosowania prawa. Wprowadza on do nich własne wypowiedzi stanowcze, których ranga jest wysoka, albowiem sa one oświadczeniami znaczącymi w swojej treści, ale są też znacząco odbierane przez adresatów, zarówno bezpośrednio wskazanych w normie indywidualno-konkretnej, jak i tych, do których odnoszą się pośrednio, jako do członków określonej społeczności ${ }^{36}$. To sprawia, że wyrok sądu może skutecznie oddziaływać na rzeczywistość prawną. Odwołując się do praw jednostki, do określonych standardów ich ochrony, zapewniając ich skuteczną realizację - rozwija ich efektywną ochronę.

Pierwszeństwo funkcji ochrony praw i wolności jednostki oraz model argumentacyjny prawa wyznacza sądownictwu administracyjnemu nową rolę i pozycję. Jest ono podmiotem wydającym właściwe rozstrzygnięcie w sprawie, które - zgodnie z koncepcja dyskursywną uzyskuje rangę wypowiedzi - komunikatu. Ten zaś wprowadzony do wspólnoty komunikacyjnej ma oddziaływać na zachowania podmiotów. Indywidualne decyzje stosowania prawa to wypowiedzi kierowane do spersonalizowanego odbiorcy, ale też do ogółu tych, którzy są uczestnikami wspólnoty. Zawieraja znaczenie, które stabilizuje się w komunikacji podejmowanej między sądem a bezpośrednim i pośrednim adresatem orzeczenia. Znaczenie powinno zostać odebrane przez podmiot wskazany w orzeczeniu. $\mathrm{Z}$ tego punktu widzenia istotne jest, by pozycja sądu konstytucyjnego, który konstytuuje normę w procesie interpretacyjnym, była wyraźna pozycja nadawcy wypowiedzi, który z kolei formułuje jasny komunikat podlegajacy realizacji. Sąd administracyjny, chroniąc prawa jednostki, w sytuacji ich naruszenia przez administrację dysponować powinien określonymi instrumentami prawnymi, które zapewnią wykonanie wyroku. W tym kontekście trzeba wspomnieć o wadze środków dyscyplinujących organy administracji publicznej. Ale sąd administracyjny powinien dysponować również władzą kierowania do organów administracji odpowiednich nakazów (power of injunction $)^{37}$. Tak należy postrzegać orzeczenia merytoryczne, które stanowia własną wypowiedź sądu o danej sprawie i otwierają możliwość prowadzenia egzekucji co do treści w niej wyrażonych. To z kolei stawia sąd administracyjny w roli podmiotu samodzielnie i aktywnie uczestniczącego $\mathrm{w}$ obronie wartości, jakimi sa prawa jednostki uznane przez system prawny.

$\mathrm{Na}$ tle wprowadzonych zmian podejmowany jest w literaturze problem zgodności przepisów o orzeczeniach merytorycznych z Konstytucja, zwłaszcza z zasada podziału władz. Zgodnie z art. 184 Konstytucji w związku z jej art. 10 , art. 173 , art. 175 ust. 1 , art. 177 i 183 ust. 1 sądy administracyjne stanowią wyodrębnioną część władzy sądowniczej i sprawują wymiar sprawiedliwości, polegający na kontroli działalności administracji publicznej, poszerzonej o orzekanie o zgodności z ustawami uchwał organów samorządu terytorialnego oraz aktów normatywnych terenowych organów administracji rządowej. Ze względu na treść art. 175 ust. 1, który wiąże państwowy wymiar sprawiedliwości z sądami wymienionymi w jego treści, przekazując

${ }^{36}$ A. Kotowski, Modele dyskursów prawniczych, Toruń 2013, s. 143.

37 Z. Kmieciak, op. cit., s. 649. 
monopol sądzenia sporów prawnych jedynie wskazanej wyraźnie części władzy sądowniczej, należy przyjąć, że kontrola realizowana przez sądy administracyjne jest szczególnym rodzajem sądzenia sporów o prawo ${ }^{38}$. Jest forma wymiaru sprawiedliwości charakteryzującą się specyficznym przedmiotem, kryterium oraz stosowanymi przez sąd środkami ${ }^{39}$. Prowadzona jest bowiem przez podmiot niepodporządkowany organizacyjnie i ustrojowo organom administracji, lecz stanowiący odrębny pion władzy. Jest sprawowana z punktu widzenia kryterium zgodności z prawem (art. $1 \S 2$ p.u.s.a.), przy czym samo pojęcie legalności nie powinno być interpretowane wąsko, w sposób formalistyczny, odwołuje się bowiem do przepisów, zasad i wartości Konstytucji, prawa UE oraz orzecznictwa trybunałów. Sądy, nie będąc organami administracji, nie rozstrzygają o istnieniu konkretnych praw stron, w sprawach objętych kontrolą sądy nie mogą zastępować organu jako podmiotu administrującego. W przypadku uchylenia bądź stwierdzenia nieważności zaskarżonego działania wydany wyrok nie kończy definitywnie postępowania, ale obliguje organ administracji do ponownego jego podjęcia w sposób zgodny z prawem ${ }^{40}$. Trafnie podkreśla się, iż sprawowanie kontroli oznacza pewnego rodzaju wtórność działań sądu wobec działania organów administracji. Rolą sądu jest badanie (korygowanie) tych działań lub zaniechań, co należy odróżnić od samodzielnego rozstrzygania spraw pozostawionego organom $^{41}$. Funkcjonujący w Polsce kasatoryjny model orzekania przewiduje bierną ochronę adresata aktu administracyjnego, gdzie bierność polega na tym, że sąd administracyjny posiada wyraźnie ograniczone prawo do rozstrzygnięcia merytorycznego sprawy co do jej istoty. W ramach modelu rozgraniczeniu podlega zatem kontrola administracji publicznej (rozstrzyganie sprawy sądowoadministracyjnej) od wykonywania administracji publicznej

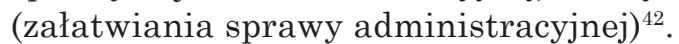

Trafnie podkreśla się w literaturze, że wprowadzenie możliwości wydawania orzeczeń merytorycznych nie powoduje zmiany reguły kompetencji kasatoryjnych sądów administracyjnych, że jest to wyłącznie poszerzenie katalogu wyjątków występujących już wcześniej w ustawie ${ }^{43}$. Określa się powyższe zmiany jako ewolucyjne, akcentując, że nie mają one na celu wkraczania przez sądy w domenę uprawnień administracji, polegajacego na zastępowaniu jej w realizacji przyznanej jej funkcji państwowej. Mają na celu wyłącznie eliminowanie najpoważniejszych naruszeń prawa przez organy, sytuacje nazywane

38 B. Adamiak, J. Borkowski, op. cit., s. 52.

${ }^{39}$ M. Jaśkowska, Możliwości reformatoryjnego orzekania sqdów administracyjnych na przykładzie spraw dostepu do informacji publicznej - głos w dyskusji, w: I. Lipowicz, Z. Kmieciak (red.), op. cit., s. 50.

${ }^{40}$ W. Piątek, Powaga rzeczy osadzonej wyroku sqdu administracyjnego, Warszawa 2015, s. $8-10$.

${ }^{41}$ L. Garlicki, Komentarz do art. 184 Konstytucji, w: L. Garlicki (red.), Konstytucja RP. Komentarz, t. 4 , s. 5 .

${ }^{42}$ R. Hauser, J. Drachal (red.), Metodyka pracy w sqdach administracyjnych, Warszawa 2015, s. 25 .

${ }^{43}$ R. Hauser, M. Wierzbowski (red.), Prawo o postepowaniu przed sadami administracyjnymi, s. 602 . 
patologicznymi, np. gdy sprawa wraca do sądu z powodu niezastosowania się przez organ do oceny prawnej zawartej w wyroku ${ }^{44}$. Zwraca się uwagę na ograniczoną dopuszczalność orzekania merytorycznego ze względu na konieczność łącznego spełnienia przesłanek ustawowych, co w praktyce będzie niezwykle rzadkie i co każe twierdzić, że nadal podstawowym sposobem orzekania będzie wydawanie wyroków kasacyjnych ${ }^{45}$. Podkreśla się, że wzbogacenie modelu kasacyjnego o merytoryczne kompetencje orzecznicze wychodzi naprzeciw pełnej realizacji konstytucyjnego prawa do sądu. Sądy administracyjne pełnia funkcję ochronną względem praw i wolności jednostki w jej stosunkach $\mathrm{z}$ administracja, a ta sądowa ochrona wynika $\mathrm{z}$ art. 45 Konstytucji, zgodnie z którym każdy ma prawo do sprawiedliwego i jawnego rozpatrzenia sprawy bez nieuzasadnionej zwłoki przez właściwy, niezależny, bezstronny i niezawisły sąd. Sądy administracyjne realizują prawo to w zakresie spraw administracyjnych poprzez efektywną kontrolę zgodności z prawem zaskarżanych aktów administracyjnych $^{46}$.

$\mathrm{Na}$ tle powyższego cenne są uwagi Zbigniewa Kmieciaka, który wskazuje na istotne zagadnienie zmian we współczesnym rozumieniu zasady podziału władz. Obecnie trudno jest precyzyjnie zdefiniować pojęcia władzy legislacyjnej, wykonawczej i sądowniczej, co utrudnia jasne wyznaczenie granic między nimi. Podział ten należy raczej postrzegać jako „dynamiczny, wieloaspektowy”. Należy mieć też na uwadze ogromną różnorodność wariantów i form realizacji wspomnianej zasady. Odchodzi się bowiem od czystego jej pojmowania jako separacji władz na rzecz wzajemnego ich wpływania i hamowania, tworzenia mechanizmów checks and balances. W tym kontekście orzekanie merytoryczne trafnie postrzega autor jako reakcje jednej władzy na niedopełnienie lub nieprawidłową realizacje obowiązków przez inną. Reakcja ta ma doprowadzić do przywrócenia stanu równowagi w wykonywaniu władzy zakłóconego bezprawnym zachowaniem poprzez zapewnienie efektywnej ochrony skarżącym. Takie pojmowanie wyróżnionej kompetencji sądów administracyjnych pozwala traktować ją jako przejaw powściagania władzy wykonawczej przez sądownicza, co odpowiada funkcjonalnemu ujęciu zasady z art. 10 Konstytucji ${ }^{47}$.

mgr Kamila Wysocka

Wyższa Szkota Bankowa w Toruniu

kamila.wysocka@wsb.torun.pl

\footnotetext{
${ }^{44}$ R. Hauser, J. Drachal, op. cit., s. 541.

45 B. Adamiak, J. Borkowski, op. cit., s. 475; H. Knysiak-Sudyka, M. Romańska, T. Woś, op. cit., s. 293-294.

${ }^{46}$ R. Hauser, J. Drachal, op. cit., s. 20.

${ }^{47}$ Z. Kmieciak, Merytoryczne orzekanie przez sady administracyjne $w$ świetle konstytucyjnej zasady podziału władz, „Przegląd Legislacyjny” 2015, nr 2, s. 16-22.
} 


\section{COMPTENCES OF ADMINISTRATIVE COURTS TO ADJUDICATE \\ AND THE IMPLEMENTATION OF THE PROTECTIVE FUNCTION OF INDIVIDUAL'S RIGHTS IN COURT PROCEEDINGS}

\section{Sum mary}

The article discusses the changes occurring in the annulment model in administrative courts jurisdiction in connection with the concepts of the effective judicial protection that have been recently developed in European 'case law' and 'soft law'. The comparison of the legal solutions adopted in Germany, Austria and Poland confirms that in each of the abovementioned countries courts have acquired competences and legal instruments appropriate for the full appeal model. One of the reasons that leads to the adoption of such changes is, among others things, low effectiveness of legal procedures, especially at the stage of judicial decisions being enforced by the public authorities. These changes, however, should be considered in a wider perspective related to the new role of administrative courts since these courts are seen as guarantors of effective protection of individual rights and as such ought to be equipped with appropriate legal instruments necessary for its implementation. 